\title{
Arsenic exposure of child populations in Northern Argentina
}

Marta Calatayud, ${ }^{\mathrm{a}}$ Silvia Sara Farias, ${ }^{\mathrm{b}}$ Gladys Soria de Paredes, ${ }^{\mathrm{c}}$ Mónica Olivera, ${ }^{\mathrm{d}}$

Natalia Ávila Carreras, ${ }^{\mathrm{e}}$ Maria Cecilia Giménez, ${ }^{\mathrm{f}}$ Vicenta Devesa, ${ }^{\mathrm{a}}$ Dinoraz Vélez ${ }^{\mathrm{a} *}$

a Instituto de Agroquímica y Tecnología de Alimentos (CSIC), C/ Agustín Escardino 7, 46980 Paterna, Valencia, Spain.

b Investigador Consulto Gerencia Química, Gerencia de Área de Seguridad y Ambiente, Comisión Nacional de Energía Atómica, Buenos Aires, Argentina.

${ }^{\mathrm{c}}$ Programa Provincial H.A.C.R.E. Ministerio de Salud, Santiago del Estero, Argentina.

d Cátedra de Toxicología y Química Legal, Facultad de Farmacia y Bioquímica, Universidad de Buenos Aires, Argentina.

e Universidad Nacional del Chaco Austral, Provincia Roque Sáenz Peña, Chaco, Argentina.

${ }^{\mathrm{f}}$ Facultad de Ciencias Agrarias, Universidad Nacional de Jujuy, Jujuy, Argentina.

* To whom correspondence should be addressed (telephone (+34) 963900 022; fax (+34) 963636 301; e-mail: deni@iata.csic.es)

Keywords. Inorganic arsenic, intakes, food, urinary arsenic metabolites, 8-oxo-7,8dihydro-2'-deoxyguanosine, Argentina 


\section{ABSTRACT}

Chronic exposure to inorganic arsenic (As) is associated with numerous adverse effects. Argentina is one of the countries affected by arsenicism; however, there are few studies that evaluate inorganic As exposure and its effects on child population. The aim of this study is to evaluate exposure to As through water and food in child populations living in the provinces of Santiago del Estero and Chaco $(n=101)$, and to determine the impact of this exposure analysing biomarkers of exposure (urine and hair As contents) and effect [8-oxo-7,8-dihydro-2'-deoxyguanosine (8-OHdG)]. The populations selected live in three areas with different levels of As in the drinking water (Santa Teresa de Carballo, 0.925 mg/L; Taco Pozo, 0.210 mg/L; Jumi Pozo, 0.016 mg/L). The As intakes through water and food are especially high in the areas with the greatest As exposure (Santa Teresa de Carballo, $1575 \pm 8 \mu \mathrm{g} /$ day; Taco Pozo, $386 \pm 8 \mu \mathrm{g} /$ day; Jumi Pozo, $39 \pm 1$ $\mu \mathrm{g} /$ day).

The total As contents in most of the samples of hair $(0.11-13.11 \mathrm{mg} / \mathrm{kg})$ and urine (31-4258 $\mu \mathrm{g} / \mathrm{g}$ creatinine) are higher than the reference values (hair: $1 \mathrm{mg} / \mathrm{kg}$; urine: 50 $\mu \mathrm{g} / \mathrm{g}$ creatinine). The increase in the level of As exposure alters the profile of metabolites in urine, with a decrease of dimethylarsinic acid (10\%) and an increase in the percentages of monomethylarsonic acid (4\%) and inorganic As (6\%). The results also show high values of 8-OHdG (3.7-37.8 $\mu \mathrm{g} / \mathrm{g}$ creatinine), a oxidative DNA damage marker, in the two areas with greater As exposure. 


\section{INTRODUCTION}

The presence of inorganic arsenic (As) in aquifers affects millions of people throughout the world (WHO, 2012). Chronic exposure to this form of As through drinking water is associated with greater prevalence of lung, urinary tract, liver and skin cancers (WHO, 2012). It also produces an increase in other pathologies, such as type 2 diabetes, cardiovascular problems (hypertension) and cerebrovascular problems (heart attacks), chronic obstructive respiratory diseases and skin pathologies (hypo- and hyperpigmentation, palmar keratosis) (Chiou et al., 1997; Rahman et al., 1999; Coronado-González et al., 2007; Lindberg et al., 2008; WHO, 2012).

Argentina is one of the countries most affected by arsenicism. The first description of hydroarsenicism in Argentina was provided by Mario Goyenechea in 1913, and a century later it is thought that at least 4 million people in this country depend on groundwater with an inorganic As content higher than the guidance value $(0.01 \mathrm{mg} / \mathrm{L}$; WHO, 2012). However, little research has been done in comparison with other endemic areas, such as India or Bangladesh. Most of the studies have focused on evaluating As contents in aquifers and sediments (Cabrera et al., 2001; Farías et al., 2003; Bundschuh et al., 2004; Gomez et al., 2009). There are fewer studies on inorganic As exposure and clinical manifestations (Concha et al., 2002; Cabrera and Gómez, 2003; Steinmaus et al., 2006). Most of these studies were conducted in adult populations, but there is insufficient research for As risk assessment in child populations (Concha et al., 1998).

Children are more susceptible than adults to the development of pathologies after chronic exposure to this metalloid. Inorganic As passes through the placenta (Vahter, 2008), and prenatal exposure can have an influence on the development of diseases in the short and long term. In populations chronically exposed during pregnancy there are reports of a series of effects on the development of the foetus and of the newborn child 
(foetal loss, infant death, increased risk of stillbirth, low birth weight, birth defects; Kwok et al., 2006; Cherry et al., 2008; Rahman et al., 2017). Studies conducted in Region II (Antofagasta) in Chile show an increase in mortality at early ages caused by liver and lung cancers in populations exposed to inorganic As only during childhood (Smith et al., 2006; Liaw et al., 2008). Exposure to As has also been linked to neurobehavioural defects during the early years of life (Tyler and Allan, 2014). Some of these adverse outcomes may be due to the influence of prenatal exposure on the expression of critical genes and proteins, partly through epigenetic mediators (Rager et al., 2017).

Integrated evaluation of the risk associated with exposure to inorganic As requires a suitable methodology for determination of As species and evaluation of intake, not only through water, the most common practice, but also by analysing foods in the form in which they are consumed. It is also necessary to evaluate the internal dose and the effects caused by the exposure by means of suitable biomarkers. One mechanism proposed for the toxic effect of As is an increase in oxidative DNA lesions (Kitchin and Ahmad, 2003). Among these oxidative DNA lesions, 8-hydroxy-2'-deoxyguanosine (8OHdG) is one of the most abundant base modifications and has attracted special attention because of its premutagenic effect (Cheng et al. 1992). The repair process for 8-OHdG damage results in excised 8-OHdG adduct excreted into the urine, a convenient biomarker of effect because it is easy to collect (Yamauchi et al., 2004).

The aim of this study was to characterize exposure of child populations in northern Argentina to inorganic As by evaluation of intake through food and water, determination of As contents in samples of urine and hair, and quantification of the urinary marker of DNA oxidative damage, 8-OHdG. 


\section{MATERIALS AND METHODS}

2.1. Study population. The study was confined to the child population attending school. A total of 101 children with ages ranging between 3 and 15 years were evaluated (table 1). They were grouped into 3 exposure levels, according to the total As concentrations found in the drinking water. The low exposure population belonged to the department of Banda, in the province of Santiago del Estero $(\mathrm{n}=26)$. It consisted of three small, scattered communities (Jumi Pozo) with mean As concentrations of $16 \mu \mathrm{g} / \mathrm{L}$ in the tube well water. The medium exposure population was located in the department of Almirante Brown (province of Chaco) $(n=60)$. It was an urban development (Taco Pozo), which had tap water with a mean As concentration of $210 \mu \mathrm{g} / \mathrm{L}$. The area with the highest exposure, Santa Teresa de Carballo, was also in the department of Almirante Brown ( $\mathrm{n}=14)$. The population was also scattered and consumed tube well water with high As contents (mean: $925 \mu \mathrm{g} / \mathrm{L}$ ).

This study was conducted according to the Declaration of Helsinki Ethical Principles for Medical Research Involving Human Subjects and was approved by the Ethics Committee of Dr. Alejandro Posadas National Hospital (Buenos Aires, Argentina). Parents gave informed consent before participation of children.

2.2. Intake evaluation. The intake of inorganic As was determined by analysing the drinking water and food. The samples of water collected from the schools were acidified and stored at $4{ }^{\circ} \mathrm{C}$ until the analysis of total As. Samples of cooked food ready for consumption were kindly donated by the schools over a period of 5 days. The samples were freeze-dried and stored at $-20{ }^{\circ} \mathrm{C}$ until analysis.

Water samples were reduced with a solution of ascorbic acid (5\% m/v, Merck) and KI (5\% m/v, Merck) prior to the determination of total As. The detection was performed 
by flow injection-hydride generation-atomic absorption spectrometry (FI-HG-AAS) using a model 3300 spectrophotometer (Perkin Elmer, PE) equipped with a flow injection system (PE FIAS-400). The analytical conditions used were the following: loop sample $0.5 \mathrm{~mL}$; reducing agent $0.2 \%(\mathrm{~m} / \mathrm{v}) \mathrm{NaBH}_{4}$ in $0.05 \%(\mathrm{~m} / \mathrm{v}) \mathrm{NaOH}, 5$ $\mathrm{mL} / \mathrm{min}$ flow rate; $\mathrm{HCl}$ solution $1.2 \mathrm{~mol} / \mathrm{L}, 10 \mathrm{~mL} / \mathrm{min}$ flow rate; carrier gas argon, 100 $\mathrm{mL} / \mathrm{min}$ flow rate; wavelength $193.7 \mathrm{~nm}$; spectral band-pass $0.7 \mathrm{~nm}$; electrodeless discharge lamp system 2, lamp current setting $400 \mathrm{~mA}$; cell temperature $900{ }^{\circ} \mathrm{C}$. Inorganic As in food was determined by acid digestion, solvent extraction and FI-HGAAS following the method developed by Muñoz et al. (1999). Intakes were calculated on the basis of a food frequency questionnaire administered at the schools and among the families.

2.3. Urine samples: collection and analysis. Early morning spot urine samples were collected in polyethylene tubes, transported to the laboratory at $4{ }^{\circ} \mathrm{C}$ and stored at -20 ${ }^{\circ} \mathrm{C}$ until the quantification of total and inorganic As metabolites. Measurements were standardized against urinary creatinine concentrations.

Total As was determined by FI-HG-AAS after a dry ashing step as described by Almela et al. (2002). The determination of As species in urine [As(III), As(V), monomethylarsonic acid (MMA) and dimethylarsinic acid (DMA)] was performed by HPLC (Perkin Elmer, model 1050) coupled to HG-AFS (atomic fluorescence spectrometry; Millennium Excalibur 10.055, PSA, UK). The chromatography separation was performed using an anion exchange column (Hamilton PRP X-100; 25.0 cm $\times 4.1 \mathrm{~mm}$; injection volume $100 \mu \mathrm{L})($ Teknokroma, Spain) eluted isocratically with ammonium phosphate buffer (Merck, Spain) at pH 5.75 (flow rate $1 \mathrm{~mL} / \mathrm{min}$ ). The HGAFS quantification conditions were: reducing agent $1.5 \%(\mathrm{~m} / \mathrm{v}) \mathrm{NaBH}_{4}$ in $0.7 \%(\mathrm{~m} / \mathrm{v})$ 
$\mathrm{NaOH}, 2.5 \mathrm{~mL} / \mathrm{min}$ flow rate; $\mathrm{HCl}$ solution $1.5 \mathrm{~mol} / \mathrm{L} 6 \mathrm{~mL} / \mathrm{min}$ flow rate; carrier gas argon, $300 \mathrm{~mL} / \mathrm{min}$ flow rate; dryer gas air, $2.5 \mathrm{~L} / \mathrm{min}$ flow rate; hydrogen $60 \mathrm{~mL} / \mathrm{min}$ flow rate; wavelength $193.7 \mathrm{~nm}$; primary current $27.5 \mathrm{~mA}$; boost current $35.0 \mathrm{~mA}$.

2.4. Scalp hair samples: collection and analysis. Hair samples were collected from the nape using stainless-steel scissors and placed in polyethylene bags for transport and storage. Before total As determination, samples were washed to avoid external contamination. Hair samples were first washed using $20 \mathrm{~mL}$ deionized water, shaking for $5 \mathrm{~min}$. Then the samples were submitted to an acetone washing step for 5 min and afterwards to a deionized water washing (20 mL, $5 \mathrm{~min}$ ). Finally, samples were dried overnight at $40{ }^{\circ} \mathrm{C}$, cut into small pieces using stainless-steel scissors, and stored in polyethylene tubes at room temperature until analysis. Total As in dried hair $(0.025 \pm$ $0.005 \mathrm{~g}$ ) was determined by dry mineralization-HG-AAS using the same protocol as described for urine samples (Almela et al., 2002).

\subsection{Determination of urinary 8-oxo-7,8-dihydro-2'-deoxyguanosine (8-OHdG).}

Urine samples were centrifuged at $15000 \mathrm{rpm}$ for $10 \mathrm{~min}$ at $4^{\circ} \mathrm{C}$. Supernatants were used for the determination of 8-OHdG using an ELISA Kit (Japan Institute for the Control of Aging, Fukuroi, Japan), following the manufacturer's instructions. Values were adjusted by urinary creatinine concentrations.

\subsection{Statistical analysis}

The results were statistically analyzed by one-factor analysis of variance (ANOVA) with Fisher HSD post hoc multiple comparison (SigmaPlot version 13.0). Differences were considered significant for $\mathrm{p}<0.05$. 


\section{RESULTS AND DISCUSSION}

3.1. Intake evaluation. From the inorganic As contents found in the food and water and the consumption data obtained from the questionnaire it was possible to calculate inorganic As intakes. For this calculation it was considered that the total As detected in water was inorganic As, as reported by all the studies on this subject (Sorg et al., 2014).

The study has only considered the meals served at school: breakfast consisting of a cup of mate infusion or chocolate milk powder ( $250 \mathrm{~mL}$ of water) and a portion of bread (45 g), a midday meal (300 g) consisting of stew, pasta or soup with meat, and an afternoon meal similar to breakfast. The evening meal, served at home, was not considered. The participants declared that they consumed $1 \mathrm{~L}$ of water, without taking the infusions into account. Table 2 shows the inorganic As intake obtained for the three exposure groups. The intakes presented clearly differentiated values in the three populations selected. In the low exposure area, the values (min-max) ranged between 33 and $45 \mu \mathrm{g} / \mathrm{day}$, in Taco Pozo (medium exposure area) the intakes varied between 360 and $431 \mu \mathrm{g} / \mathrm{day}$, and in San Teresa de Carballo (the highest exposure area) the values ranged between 1530 and $1620 \mu \mathrm{g} /$ day.

To evaluate the risk, the intakes obtained were compared with the benchmark dose lower confidence limit for a $0.5 \%$ increased incidence of lung cancer $\left(\mathrm{BMDL}_{0.5}: 3.0\right.$ $\mu \mathrm{g} / \mathrm{kg}$ body weight/day) established by the Joint FAO/WHO Expert Committee on Food Additives (JECFA, 2011). The evaluation of inorganic As intake from water and food exceeds this limit in the medium and high exposure areas, while in the low exposure area the mean intake ranges between 22 to $86 \%$ of the $\mathrm{BMDL}_{0.5}$, depending on the body weight. These results indicate risk situations for the child populations in Taco Pozo (intake between 2 and 7 times greater than the $\mathrm{BMDL}_{0.5}$ ) and, especially, in Santa Teresa de Carballo, where the intake is $10-40$ times greater than the $\mathrm{BMDL}_{0.5}$. These 
high intakes would be much higher if the evening meal would have been included in the study.

In a study conducted in Bangladesh, Wasserman et al. (2004) reported that exposure to As was associated with reduced intellectual function in a dose-response manner, such that children with exposures $>50 \mu \mathrm{g} / \mathrm{L}$ in drinking water received significantly lower performance and full-scale scores than children with exposures $<5.5 \mu \mathrm{g} / \mathrm{L}$. The children belonging to the medium and high exposure areas greatly exceed those concentrations.

The data obtained in this study also indicate that food is an important source of inorganic As and that its contribution must be considered when making risk assessments. In the low exposure area, food contributes a greater quantity of inorganic As (58\%) to the diet than water. In the medium and high exposure areas, the mean contribution from food alone, 176 and $650 \mu \mathrm{g}$ inorganic As/day respectively, exceeds the reference value. These data are of special interest because, in addition to showing a worrying situation for the child populations studied, they are also the first data concerning the contribution of inorganic As from food in Argentina.

3.2. Total urinary As and inorganic As metabolites. As part of the exposure evaluation, As contents of the urine of 101 children were analysed. Table 3 shows contents of total and inorganic As metabolites found in the three exposure groups.

The background concentration of inorganic As and its metabolites for non-exposed individuals is considered to be $8 \pm 6 \mu \mathrm{g}$ As/g creatinine (Vahter, 1986). In the study populations, all the participants exceeded this background value. Most of the individuals studied (98\%) also exceeded the biological exposure index for inorganic As plus methylated metabolites (35 $\mu \mathrm{g}$ As/L; $50 \mu \mathrm{g} / \mathrm{g}$ creatinine) proposed by the American Conference of Governmental Industrial Hygienists (ACGIH, 2001). Moreover, the 
urinary levels in these Argentinian school populations, especially in Santa Teresa de Carballo, are much higher than those reported for child populations in other As-endemic areas (28-437 g/g creatinine; Calderón et al., 2001; Rosado et al., 2007; Xu et al., 2008).

According to the data in the literature, the As contents in urine of the medium and high exposure populations exceeded the concentrations that could reduce children's cognitive functions. Calderón et al. (2001) found that urinary As concentration was inversely correlated with verbal intelligence quotients (IQ), concepts factor (language), and knowledge factor (verbal comprehension and long-term memory) in a study conducted in Mexico in which the urinary As contents in the children did not exceed $187 \mu \mathrm{g}$ As/g creatinine.

The data for total As in urine confirm the risk situation which had already been shown in the evaluation of the inorganic As intake. However, these results in urine provide a more direct evaluation of exposure, as they are a biomarker of internal dose. It is noteworthy that the evaluation of intake through water and food does not show a risk situation in the low exposure area, whereas the urinary As contents show a different scenario, with concentrations of As in urine that in many cases are higher than the reference values.

With regard to the urinary metabolites, it is important to emphasize the high concentrations of monomethylated As found in Santa Teresa de Carballo (min-max: 189-1157 $\mu \mathrm{g}$ As/g creatinine). A study conducted in Mexico (Del Razo et al., 1997) reported urinary levels of MMA in adult populations with skin lesions (geometric mean: $95.2 \mu \mathrm{g} / \mathrm{g}$ creatinine) lower than those found in the child population of Santa Teresa de Carballo. On the other hand, studies showed that individuals who excreted a higher 
proportion of MMA were more susceptible to As-related diseases, including cancers (Tseng et al., 2005; Steinmaus et al., 2006).

By expressing the concentrations of As species as percentages of the total As concentration it can be seen that in the low and medium exposure levels the urinary profile followed a very similar pattern, but in individuals in Santa Teresa de Carballo a statistically significant decrease in the DMA concentration in urine (10\%) was detected, combined with increases in the levels of inorganic As (6\%) and MMA (4\%). This change in the urinary profile means an increase in the more toxic metabolites of inorganic As, with the consequent toxicological connotations.

3.3. Total As in hair. As a continuation of the exposure evaluation, the samples of hair were analysed after being washed with water and acetone. The percentage of As eliminated during the washing was between 0.2 and $5 \%$ of the total. The mean As contents in the washed hair were $1.1,3.0$ and $4.9 \mathrm{mg} / \mathrm{kg}$ for low, medium and high exposed children, respectively (figure 1). Concentrations in hair samples from residents of Northern Sweden without occupational or environmental exposure to As range from 0.03 to $0.32 \mathrm{mg} / \mathrm{kg}$ (Rodushkin and Axelsson, 2000). In general, hair As concentrations in non-exposed population do not exceed $1 \mathrm{mg} / \mathrm{kg}$ (WHO, 1984). In our study, 84\% of the children studied exceed these values.

Some studies have linked As exposure via hair As contents and neurological development in child population. Siripitayakunkit et al. (1999) showed, in children from an endemic area of Thailand, that As hair concentrations above $2 \mathrm{mg} / \mathrm{kg}$ were associated with a 0.75-point decrease in intellectual quotients and As levels above $5 \mathrm{mg} / \mathrm{kg}$ with a 2-point decrease. 
3.4. Urinary concentrations of 8-OHdG. As part of the evaluation of the As exposure effects, urinary 8-OHdG concentrations of 68 children were determined. The values obtained ranged (min-max) between 3.7 and $28.8 \mu \mathrm{g} / \mathrm{g}$ creatinine $(1.5-11.5 \mu \mathrm{mol} / \mathrm{mol}$ creatinine) for the Taco Pozo population and between 7.5 and $37.8 \mu \mathrm{g} / \mathrm{g}$ creatinine (3.0$15.1 \mu \mathrm{mol} / \mathrm{mol}$ creatinine) for the Santa Teresa de Carballo population (figure 2). There were not statistically significant differences between both exposure groups. The values found in this work are similar to those reported in other child populations exposed to As (0.4-59.7 $\mu \mathrm{g} / \mathrm{g}$ creatinine, Wong et al., 2005; Xu et al., 2008), and higher than those observed in healthy non-exposed populations (1.1-6.8 $\mu \mathrm{mol}$ 8-OHdG/mol creatinine, Drury et al., 1998).

Oxidative stress is one of several proposed mechanisms of action for As-induced toxicity and carcinogenesis (Rossman, 2003). In a long-term study of carcinogenesis in rats, hepatic 8-OHdG levels increased in DMA-treated rats, suggesting an increased effect of ROS on DNA (Wanibuchi et al., 1997). In studies conducted in exposed populations in Taiwan, Thailand and Japan (Matsui et al., 1999) it was shown that the frequency of 8-OHdG positive tumours was significantly higher in As-induced epidermal neoplasms than in As-unrelated epidermal neoplasms.

\section{CONCLUSIONS}

The present study had 2 main limitations related to logistic difficulties since some of the affected areas were disperse populations with limited accessibility: lack of home served meals and low participation of disperse communities. Despite these limitations, the results obtained in the present study show unequivocally a high exposure to inorganic As in child populations in Northern Argentina. The intake of inorganic As (water and food) and the values of the biomarkers of exposure and effect analysed exceed the 
reference values in most of the participants in the populations studied. This situation shows the need to conduct more detailed studies to consider other parameters, especially neurobehavioural parameters, to evaluate the possible effects of this chronic exposure to the metalloid.

\section{ACKNOWLEDGEMENTS}

This work was supported by projects AECID-A/019010/08 and CSIC 200870I232, for which the authors are deeply indebted. Marta Calatayud received a Personnel Training Grant from the Spanish Ministry of Science and Education to carry out this study. The authors are grateful to the teachers in the schools for their disinterested collaboration, without which this research could not have been conducted.

\section{REFERENCES}

ACGIH, 2001. American Conference of Government Industrial Hygienists (ACGIH), 2001. Documentation of biological exposure indices. 7th edition. Cincinnati (OH): ACGIH Worldwide.

Almela, C., Algora, S., Benito, V., Clemente, M.J., Devesa, V., Súñer, M.A., Vélez, D., Montoro, R., 2002. Heavy metal, total arsenic, and inorganic arsenic contents of algae food products. J. Agric. Food Chem. 50, 918-923.

Bundschuh, J., Farias, B., Martin, R., Storniolo, A., Bhattacharya, P., Cortes, J., Bonorino, G., Albouy, R., 2004. Groundwater arsenic in the Chaco-Pampean Plain, Argentina: Case study from Robles county, Santiago del Estero Province. Appl. Geochem. 19, 231-243.

Cabrera, A., Blarasin, M., Villalba, G., 2001. Groundwater contaminated with arsenic and fluoride in the Argentine pampean plain. J. Environ. Hydrol. 9, XXI-XXII. 
Cabrera, H.N., Gómez, M.L., 2003. Skin cancer induced by arsenic in the water. J. Cutan. Med. Surg. 7, 106-111.

Calderón, J., Navarro, M.E., Jimenez-Capdeville, M.E., Santos-Diaz, M.A., Golden, A., Rodriguez-Leyva, I., Borja-Aburto, V., Díaz-Barriga, F., 2001. Exposure to arsenic and lead and neuropsychological development in Mexican children. Environ. Res. 85, 69-76.

Cheng, K.C., Cahill, D.S., Kasai, H., Nishimura, S., Loeb, L.A., 1992.8 8Hydroxyguanine, an abundant form of oxidative DNA damage, causes G-T and A-C substitutions. J. Biol. Chem. 267, 166-172.

Cherry, N., Shaikh, K., McDonald, C., Chowdhury, Z., 2008. Stillbirth in rural Bangladesh: Arsenic exposure and other etiological factors: A report from Gonoshasthaya Kendra. Bull. World Health Organ. 86, 172-177.

Chiou, H.Y., Huang, W.I., Su, C.L., Chang, S.F., Hsu, Y.H., Chen, C.J., 1997. Doseresponse relationship between prevalence of cerebrovascular disease and ingested inorganic arsenic. Stroke 28, 1717-1723.

Concha, G., Nermell, B., Vahter, M., 1998. Metabolism of inorganic arsenic in children with chronic high arsenic exposure in northern Argentina. Environ. Health Perspect. 106, 355-359.

Concha, G., Vogler, G., Nermell, B., Vahter, M., 2002. Intra-individual variation in the metabolism of inorganic arsenic. Int. Arch. Occup. Environ. Health, 75, 576-580.

Coronado-González, J.A., Del Razo, L.M., García-Vargas, G., Sanmiguel-Salazar, F., Escobedo de la Peña, J., 2007. Inorganic arsenic exposure and type 2 diabetes mellitus in Mexico. Environ. Res. 104, 383-389.

Del Razo, L.M., García-Vargas, G.G., Vargas, H., Albores, A., Gonsebatt, M.E., Montero, R., Ostrosky-Wegman, P., Kelsh M., Cebrián, M.E., 1997. Altered profile 
of urinary arsenic metabolites in adults with chronic arsenicism. A pilot study. Arch. Toxicol. 71, 211-217.

Drury, J.A., Jeffers, G., Cooke, R.W., 1998 Urinary 8-hydroxydeoxyguanosine in infants and children. Free Radic Res. 28, 423-428.

Farías, S.S., Casa, V.A., Vázquez, C., Ferpozzi, L., Pucci, G.N., Cohen, I.M., 2003. Natural contamination with arsenic and other trace elements in ground waters of Argentine Pampean Plain. Sci. Total Environ. 309, 187-199.

Gomez, M.L., Blarasin, M.T., Martínez, D.E., 2009. Arsenic and fluoride in a loess aquifer in the central area of Argentina. Environ. Geol. 57, 143-155.

JECFA, Joint FAO/WHO Expert Committee on Food Additives, 2011. Evaluation of certain contaminants in food. Seventy-second report of the Joint FAO/WHO Expert Committee on Food Additives. WHO Technical Report Series, no. 959. WHO Library Cataloguing-in-Publication Data, World Health Organization.

Kitchin, K.T., Ahmad, S., 2003. Oxidative stress as a possible mode of action for arsenic carcinogenesis. Toxicol. Lett. 137, 3-13.

Kwok, R.K., Kaufmann, R.B., Jakariya, M., 2006. Arsenic in drinking-water and reproductive health outcomes: A study of participants in the Bangladesh integrated nutrition programme. J. Health Popul. Nutr. 24, 190-205.

Liaw, J., Marshall, G., Yuan, Y., Ferreccio, C., Steinmaus, C., Smith, A.H., 2008. Increased childhood liver cancer mortality and arsenic in drinking water in northern Chile. Cancer Epidemiol. Biomarkers Prev. 17, 1982-1987.

Lindberg, A.L., Rahman, M., Persson, L.A., Vahter, M., 2008. The risk of arsenic induced skin lesions in Bangladeshi men and women is affected by arsenic metabolism and the age at first exposure. Toxicol. Appl. Pharmacol. 203, 9-16. 
Matsui, M., Nishigori, C., Toyokuni, S., Takada, C., Akaboshi’ M., Ishikawa, M., Imamura, S., Miyach, Y., 1999. The role of oxidative DNA damage in human arsenic carcinogenesis: Detection of 8-hydroxy-2'-deoxyguanosine in arsenic-related Bowen’s Disease. J. Investig. Dermatol. 113, 26-31.

Muñoz, O., Vélez, D., Montoro, R., 1999. Optimization of the solubilization, extraction and determination of inorganic arsenic $[\mathrm{As}(\mathrm{III})+(\mathrm{As}(\mathrm{v})]$ in seafood products by acid digestion, solvent extraction and hydride generation atomic absorption spectrometry. Analyst 124, 601-607.

Rager, J.E., Auerbach, S.S., Chappell, G.A., Martin, E., Thompson, C.M., Fry, R.C., 2017. Benchmark dose modeling estimates of the concentrations of inorganic arsenic that induce changes to the neonatal transcriptome, proteome, and epigenome in a pregnancy cohort. Chem. Res. Toxicol. 30, 1911-1920.

Rahman, M., Tondel, M., Ahmad, S.A., Chowdhury, I.A., Faruquee, M.H., Axelson, O., 1999. Hypertension and arsenic exposure in Bangladesh. Hypertension 33, 74-78.

Rahman, M.L., Valeri, L., Kile, M.L., Mazumdar, M., Mostofa, G., Qamruzzaman, Q., Rahman, M., Baccarelli, A., Liang, L., Hauser, R., Christiani, D.C., 2017. Investigating causal relation between prenatal arsenic exposure and birthweight: Are smaller infants more susceptible? Environ. Int. 108, 32-40.

Rodushkin, I., Axelsson, M.D., 2000. Application of double focusing sector field ICPMS for multielemental characterization of human hair and nails. Part II. A study of the inhabitants of northern Sweden. Sci. Total Environ. 262, 21-36.

Rosado, J.L., Ronquillo, D., Kordas, K., Rojas, O., Alatorre, J., Lopez, P., GarciaVargas, G., del Carmen Caamaño, M., Cebrián, M.E., Stoltzfus, R.J., 2007. Arsenic exposure and cognitive performance in Mexican schoolchildren. Environ. Health Perspect. 115, 1371-1375. 
Rossman, T.G., 2003. Mechanisms of arsenic carcinogenesis: an integrated approach. Mutat. Res. 533, 37-65.

Siripitayakunkit, U., Visudhiphan, P., Pradipasen, M., Vorapongsathron, T., 1999. The relationship between chronic exposure on arsenic and children's intelligence in Thailand. In: Chappell, W.R., Abernathy, C.O., Calderon, R.L. (Eds.), Arsenic exposure and health effects III. Elsevier Science, Amsterdam, pp. 141-149.

Smith, A.H., Marshall, G., Yuan, Y., Ferreccio, C., Liaw, J., von Ehrenstein, O., Steinmaus, C., Bates, M.N., Selvin, S., 2006. Increased mortality from lung cancer and bronchiectasis in young adults after exposure to arsenic in utero and in early childhood. Environ. Health Perspect. 114, 1293-1296.

Sorg, T.J., Chen, A.S., Wang, L., 2014. Arsenic species in drinking water wells in the USA with high arsenic concentrations. Water Res. 48, 156-169.

Steinmaus, C., Bates, M.N., Yuan, Y., Kalman, D., Atallah, R., Rey, O.A., Biggs, M.L., Hopenhayn, C., Moore, L.E., Hoang, B.K., Smith, A.H., 2006. Arsenic methylation and bladder cancer risk in case-control studies in Argentina and the United States. J. Occup. Environ. Med. 48, 478-488.

Tseng, C.H., Huang, Y.K., Huang, Y.L., Chung, C.J., Yang, M.H., Chen, C.J., Hsueh, Y.M., 2005. Arsenic exposure, urinary arsenic speciation, and peripheral vascular disease in blackfoot disease-hyperendemic villages in Taiwan. Toxicol. Appl. Pharmacol. 206, 299-308.

Tyler, C.R., Allan, A.M., 2014. The effects of arsenic exposure on neurological and cognitive dysfunction in human and rodent studies: A review. Curr. Environ. Health Rep. 1, 132-147.

Vahter, M., 1986. Environmental and occupational exposure to inorganic arsenic. Acta Pharmacol. Toxicol. 59, 31-34. 
Vahter, M., 2008. Health effects of early life exposure to arsenic. Basic Clin. Pharmacol. Toxicol. 102. 204-211.

Wanibuchi, H., Hori, T., Meenakshi, V., Ichihara, T., Yamamoto, S., Yano, Y., Otani, S., Nakae, D., Konishi, Y., Fukushima, S., 1997. Promotion of rat hepatocarcinogenesis by dimethylarsinic acid: association with elevated ornithine decarboxylase activity and formation of 8-hydroxydeoxyguanosine in the liver. Jpn. J. Cancer Res. 88, 1149-1154.

Wasserman, G.A., Liu, X., Parvez, F., Ahsan, H., Factor-Litvak, P., van Geen, A., Slavkovich, V., Lolacono, N.J., Cheng, Z., Hussain, I., Momotaj, H., Graziano, J.H., 2004. Water arsenic exposure and children's intellectual function in Araihazar, Bangladesh. Environ. Health Perspect. 112, 1329-1333.

WHO (World Health Organization), 1981. Environmental health criteria 18: Arsenic. Geneva, WHO.

WHO, World Health Organization, 2012. Arsenic. Fact sheet no. 372. htpp://www.who.int/mediacentre/factsheets/fs372/en/.

Wong, R.H., Kuo, C.Y., Hsu, M.L., Wang, T.Y., Chang, P.I., Wu, T.H., Huang, S., 2005. Increased levels of 8-Hydroxy-2'-Deoxyguanosine attributable to carcinogenic metal exposure among schoolchildren. Environ. Health Perspect. 113, 1386-1390.

Xu, Y., Wang, Y., Zheng, Q., Li, X., Li, B., Jin, Y., Sun, X., Sun, G., 2008. Association of oxidative stress with arsenic methylation in chronic arsenic-exposed children and adults. Toxicol. Appl. Pharmacol. 232, 142-149.

Yamauchi, H., Aminaka, Y., Yoshida, K., Sun, G., Pi, J., Waalkes, M.P., 2004. Evaluation of DNA damage in patients with arsenic poisoning: urinary 8hydroxydeoxyguanine. Toxicol. Appl. Pharmacol. 198, 291-296. 
Table 1. Characteristics of the child population studied.

\begin{tabular}{|c|c|c|c|c|c|}
\hline \multirow[b]{2}{*}{ Age (years) } & \multirow[b]{2}{*}{$\mathrm{n}$} & \multicolumn{2}{|c|}{ Gender } & \multirow{2}{*}{$\begin{array}{l}\text { Body weight (kg) } \\
\text { range (media) }\end{array}$} & \multirow{2}{*}{$\begin{array}{l}\text { Body mass } \\
\text { index }\end{array}$} \\
\hline & & male & female & & \\
\hline \multicolumn{6}{|l|}{ Jumi Pozo } \\
\hline All & 26 & $14(54 \%)$ & $12(46 \%)$ & $18.3-58.5(33.1)$ & $14.8-23.1$ \\
\hline $3-9$ & $10(38 \%)$ & $6(60 \%)$ & $4(40 \%)$ & $18.3-24.6(20.8)$ & $14.8-15.6$ \\
\hline $10-15$ & $16(58 \%)$ & $8(50 \%)$ & $8(50 \%)$ & $27.5-58.5(41.6)$ & $15.3-23.1$ \\
\hline \multicolumn{6}{|l|}{ Taco Pozo } \\
\hline All & 60 & $26(43 \%)$ & $34(57 \%)$ & $17.0-58.3(30.2)$ & $14.1-24.0$ \\
\hline $3-9$ & $36(60 \%)$ & $20(56 \%)$ & $16(44 \%)$ & $17.0-40.5(25.4)$ & 14.1-19.4 \\
\hline $10-15$ & $24(40 \%)$ & $6(25 \%)$ & $18(75 \%)$ & 26.9-58.3 (37.9) & $14.4-24.0$ \\
\hline \multicolumn{6}{|c|}{ Santa Teresa de Carballo } \\
\hline All & 14 & $8(57 \%)$ & $6(43 \%)$ & $13.3-51.3(28.2)$ & $14.9-21.6$ \\
\hline $3-9$ & $9(64 \%)$ & $6(67 \%)$ & $3(33 \%)$ & $13.3-27.2(21.4)$ & $14.9-18.3$ \\
\hline $10-15$ & $5(36 \%)$ & $2(40 \%)$ & $3(60 \%)$ & $34.8-51.3(40.5)$ & $15.9-21.6$ \\
\hline
\end{tabular}


Table 2. Inorganic arsenic intake in the three exposed populations. Values expressed as $\mu$ g inorganic As/day and percentage with respect to the total dietary intake $(n=5)$.

\begin{tabular}{|c|c|c|c|}
\hline Variable & Media \pm SE & Median (Range) & $\begin{array}{c}\text { Percentage } \\
\text { (respect to total } \\
\text { intake) }\end{array}$ \\
\hline \multicolumn{4}{|l|}{ Jumi Pozo } \\
\hline Water & $16 \pm 1$ & $18(10-22)$ & 42 \\
\hline Food (solid/liquid) & $23 \pm 1$ & $15(6-17)$ & 58 \\
\hline Water and Food & $39 \pm 1$ & $42(30-45)$ & \\
\hline \multicolumn{4}{|l|}{ Taco Pozo } \\
\hline Water & $210 \pm 5^{*}$ & $209(192-240)$ & 55 \\
\hline Food (solid/liquid) & $176 \pm 8^{*}$ & $157(150-221)$ & 45 \\
\hline Water and Food & $386 \pm 8^{*}$ & 367 (360-431) & \\
\hline \multicolumn{4}{|c|}{ Santa Teresa de Carballo } \\
\hline Water & $925 \pm 26^{*}$ & 972 (770-988) & 59 \\
\hline Food (solid/liquid) & $650 \pm 8^{*}$ & $655(605-688)$ & 41 \\
\hline Water and Food & $1575 \pm 8^{*}$ & $1580(1530-1620)$ & \\
\hline
\end{tabular}

* Significant differences with respect to the low-exposed area ( $<<0.001)$. 
Table 3. Total arsenic and inorganic arsenic urinary metabolites in child populations. Values expressed as $\mu \mathrm{g}$ of As/g creatinine and as percentage with respect to As contents.

\begin{tabular}{|c|c|c|c|}
\hline Variable & Media \pm SE & Median (Range) & $\begin{array}{c}\text { Percentage } \\
\text { (\% respect to total) }\end{array}$ \\
\hline \multicolumn{4}{|l|}{ Jumi Pozo } \\
\hline Total As & $126 \pm 19$ & $93(31-351)$ & \\
\hline $\mathrm{As}(\mathrm{V})$ & $4 \pm 2$ & $0.2(0-21)$ & 6 \\
\hline $\mathrm{As}(\mathrm{III})$ & $13 \pm 3$ & $9(3-40)$ & 11 \\
\hline MMA & $17 \pm 3$ & $13(3-57)$ & 12 \\
\hline DMA & $94 \pm 13$ & $75(28-233)$ & 77 \\
\hline \multicolumn{4}{|l|}{ Taco Pozo } \\
\hline Total As & $731 \pm 39^{*}$ & $661(311-1867)$ & \\
\hline $\mathrm{As}(\mathrm{V})$ & $23 \pm 2^{*}$ & $20(4-61)$ & 3 \\
\hline As(III) & $83 \pm 6^{*}$ & $70(29-193)$ & 11 \\
\hline MMA & $84 \pm 5^{*}$ & $69(24-209)$ & 12 \\
\hline DMA & $553 \pm 32^{*}$ & $490(250-1544)$ & 76 \\
\hline \multicolumn{4}{|c|}{ Santa Teresa de Carballo } \\
\hline Total As & $2387 \pm 165^{* *}$ & 2175 (1087-4258) & \\
\hline $\mathrm{As}(\mathrm{V})$ & $89 \pm 10^{* *}$ & $74(41-233)$ & 4 \\
\hline As(III) & $351 \pm 19^{* *}$ & $329(215-560)$ & 16 \\
\hline MMA & $406 \pm 47^{* *}$ & 397 (189-1157) & 16 \\
\hline DMA & $1528 \pm 110^{* *}$ & $1273(587-2586)$ & 64 \\
\hline
\end{tabular}

*, ** Significant differences with respect to the low-exposed area $\left({ }^{*} \mathrm{p}<0.05,{ }^{* *} \mathrm{p}<0.001\right)$. 
Figure 1. Hair arsenic contents in the child populations. Values expressed as mg/kg.

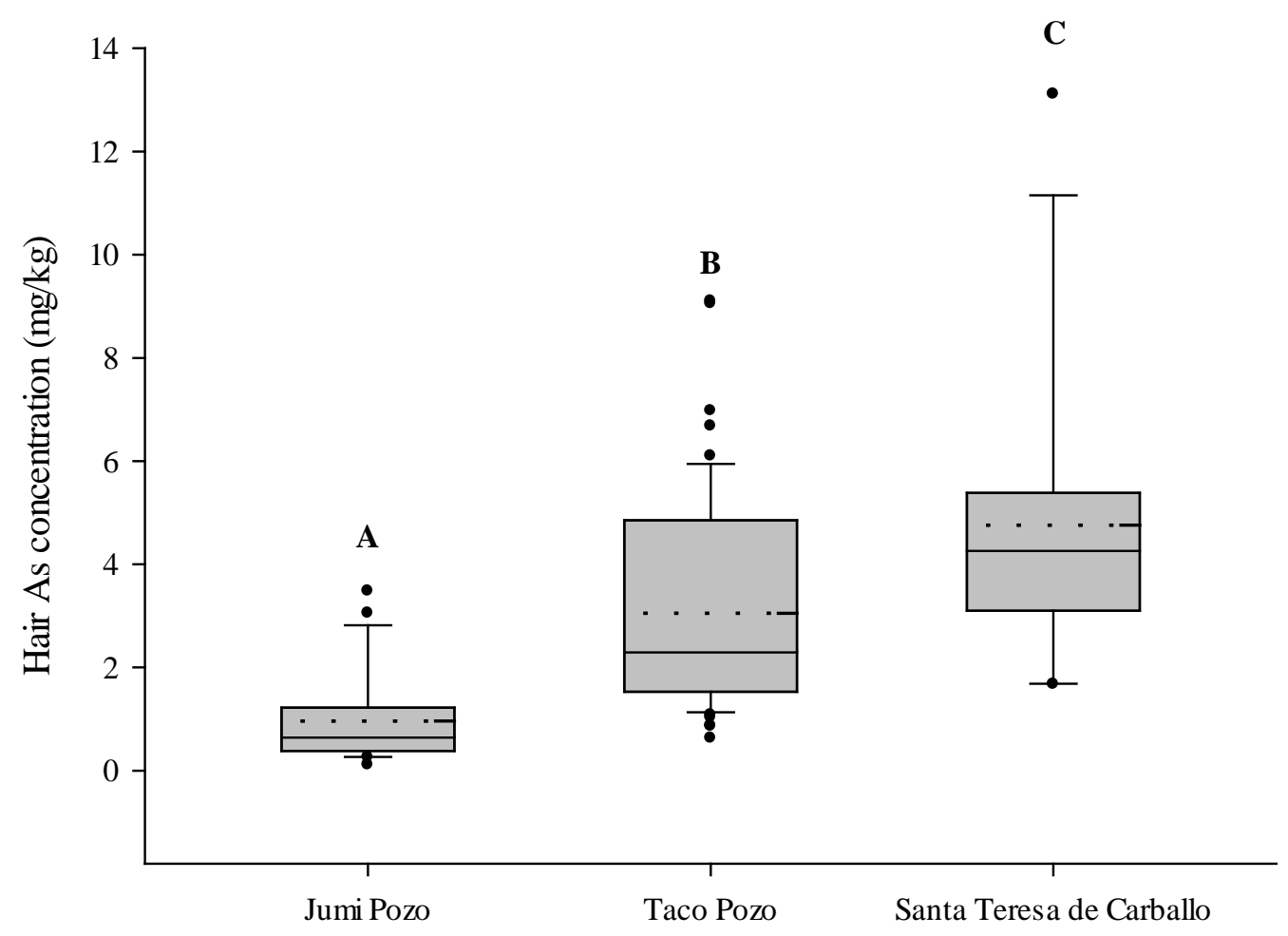

The boundaries of the box represent percentiles $25^{\text {th }}$ and $75^{\text {th }}$. Lines indicate media (solid line) and median (dashed line), whiskers below and above the box percentiles $10^{\text {th }}$ and $90^{\text {th }}$, and dots the outlying data. Different letters indicate significant differences between groups $(\mathrm{p}<0.05)$. 
Figure 2. Urinary 8-OHdG concentrations of child populations at Taco Pozo and Santa Teresa de Carballo. Values expressed as $\mu \mathrm{g} / \mathrm{g}$ creatinine.

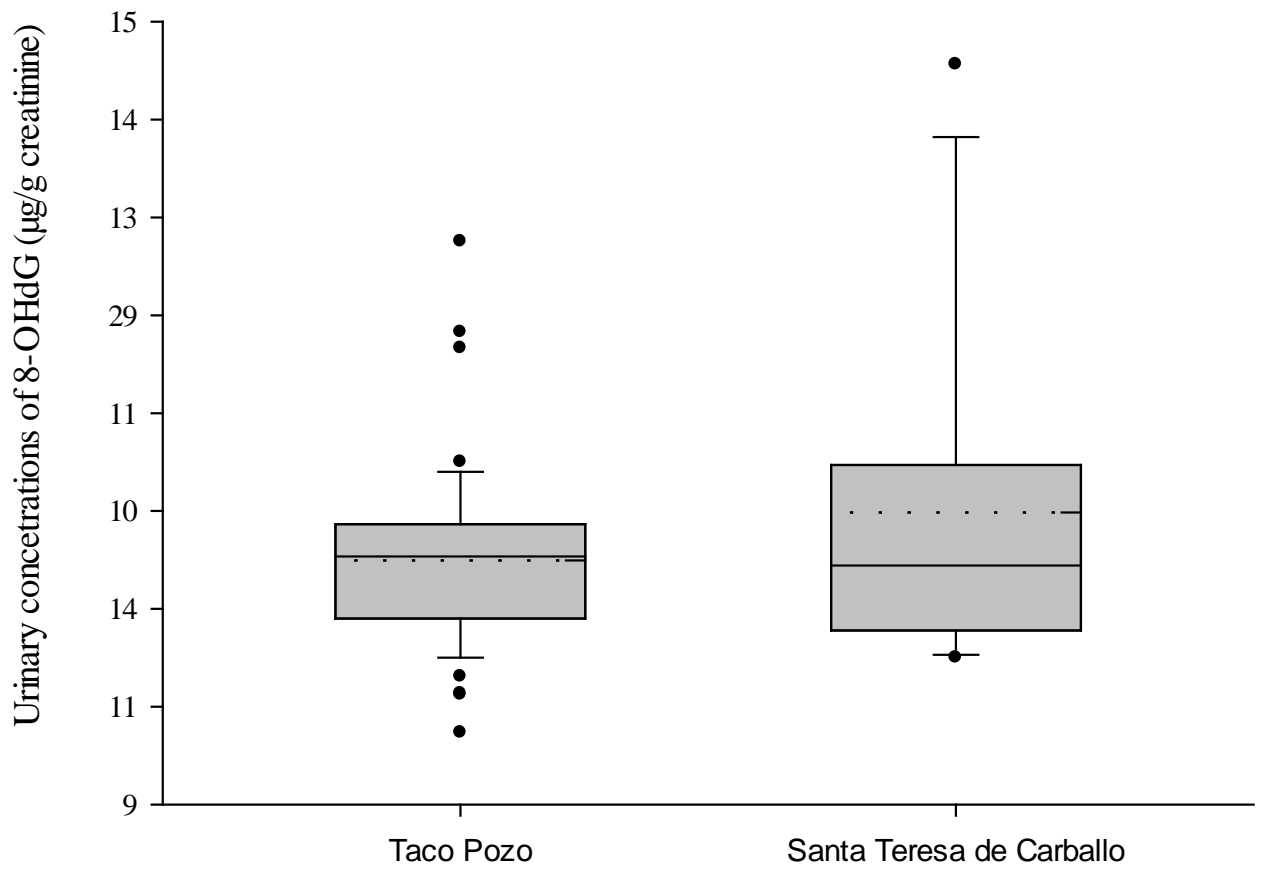

The boundaries of the box represent percentiles $25^{\text {th }}$ and $75^{\text {th }}$. Lines indicate media (solid line) and median (dashed line), whiskers below and above the box percentiles $10^{\text {th }}$ and $90^{\text {th }}$, and dots the outlying data. Different letters indicate significant differences between groups $(\mathrm{p}<0.05)$. 


\section{Graphical abstract}

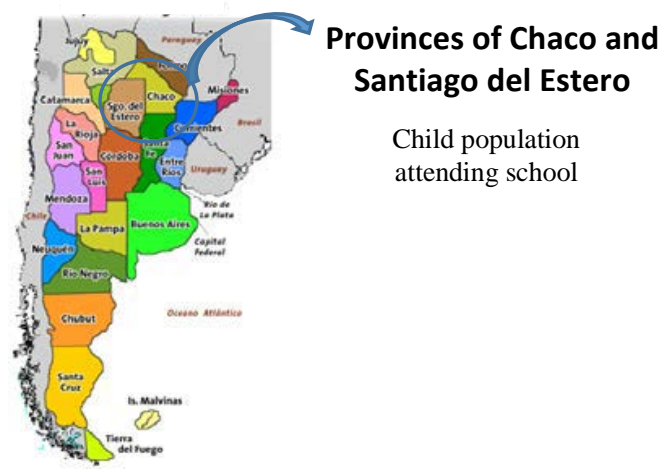

\section{As exposure}

- Inorganic As (water and food)

- Total As in

- Total urinary As and metabolites

- Urinary concentrations of 8- 